\title{
Dietary Carotenoids and Risk of Colorectal Cancer in a Pooled Analysis of 11 Cohort Studies
}

Citation for published version (APA):

Männistö, S., Yaun, S. S., Hunter, D. J., Spiegelman, D., Adami, H. O., Albanes, D., van den Brandt, P. A., Buring, J. E., Cerhan, J. R., Colditz, G. A., Freudenheim, J. L., Fuchs, C. S., Giovannucci, E., Alexandra Goldbohm, R., Harnack, L., Leitzmann, M., McCullough, M. L., Miller, A. B., Rohan, T. E., ... Smith Warner, S. A. (2007). Dietary Carotenoids and Risk of Colorectal Cancer in a Pooled Analysis of 11 Cohort Studies. American Journal of Epidemiology, 165(3), 246-255. https://doi.org/10.1093/aje/kwk009

Document status and date:

Published: 01/02/2007

DOI:

10.1093/aje/kwk009

Document Version:

Publisher's PDF, also known as Version of record

\section{Please check the document version of this publication:}

- A submitted manuscript is the version of the article upon submission and before peer-review. There can be important differences between the submitted version and the official published version of record.

People interested in the research are advised to contact the author for the final version of the publication, or visit the DOI to the publisher's website.

- The final author version and the galley proof are versions of the publication after peer review.

- The final published version features the final layout of the paper including the volume, issue and page numbers.

Link to publication

\footnotetext{
General rights rights.

- You may freely distribute the URL identifying the publication in the public portal. please follow below link for the End User Agreement:

www.umlib.nl/taverne-license

Take down policy

If you believe that this document breaches copyright please contact us at:

repository@maastrichtuniversity.nl

providing details and we will investigate your claim.
}

Copyright and moral rights for the publications made accessible in the public portal are retained by the authors and/or other copyright owners and it is a condition of accessing publications that users recognise and abide by the legal requirements associated with these

- Users may download and print one copy of any publication from the public portal for the purpose of private study or research.

- You may not further distribute the material or use it for any profit-making activity or commercial gain

If the publication is distributed under the terms of Article $25 \mathrm{fa}$ of the Dutch Copyright Act, indicated by the "Taverne" license above, 


\title{
Meta-Analysis
}

\section{Dietary Carotenoids and Risk of Colorectal Cancer in a Pooled Analysis of 11 Cohort Studies}

\author{
Satu Männistö ${ }^{1}$, Shiaw-Shyuan Yaun ${ }^{2}$, David J. Hunter ${ }^{2,3,4}$, Donna Spiegelman², Hans-Olov \\ Adami $^{5}$, Demetrius Albanes ${ }^{6}$, Piet A. van den Brandt', Julie E. Buring ${ }^{2,3}$, James R. Cerhan ${ }^{8}$, \\ Graham A. Colditz ${ }^{2,4}$, Jo L. Freudenheim ${ }^{9}$, Charles S. Fuchs ${ }^{3,10}$, Edward Giovannucci ${ }^{2,3}$, \\ R. Alexandra Goldbohm ${ }^{11}$, Lisa Harnack ${ }^{12}$, Michael Leitzmann ${ }^{6}$, Marjorie L. McCullough ${ }^{13}$, \\ Anthony B. Miller ${ }^{14}$, Thomas E. Rohan ${ }^{15}$, Arthur Schatzkin ${ }^{6}$, Jarmo Virtamo ${ }^{1}$, Walter C. Willett ${ }^{2,3,4}$, \\ Alicja Wolk ${ }^{5}$, Shumin M. Zhang ${ }^{2,3}$, and Stephanie A. Smith-Warner ${ }^{2}$
}

${ }^{1}$ National Public Health Institute, Helsinki, Finland.

${ }^{2}$ Harvard School of Public Health, Boston, MA.

${ }^{3}$ Harvard Medical School/Brigham and Women's Hospital, Boston, MA.

${ }^{4}$ Harvard Center for Cancer Prevention, Boston, MA.

${ }^{5}$ Karolinska Institute, Stockholm, Sweden.

${ }^{6}$ National Cancer Institute, Bethesda, MD.

${ }^{7}$ Faculty of Health Sciences, Maastricht University, Maastricht, the Netherlands.

${ }^{8}$ Mayo Clinic College of Medicine, Rochester, MN.

${ }^{9}$ University at Buffalo, State University of New York, Buffalo, NY.

${ }^{10}$ Dana-Farber Cancer Institute, Boston, MA.

${ }^{11}$ TNO Quality of Life, Zeist, the Netherlands.

${ }^{12}$ School of Public Health, University of Minnesota, Minneapolis, MN.

${ }^{13}$ American Cancer Society, Atlanta, GA.

${ }^{14}$ Faculty of Medicine, University of Toronto, Toronto, Ontario, Canada.

${ }^{15}$ Albert Einstein College of Medicine, Bronx NY.

Received for publication August 26, 2005; accepted for publication June 20, 2006.

Dietary carotenoids have been hypothesized to protect against epithelial cancers. The authors analyzed the associations between intakes of specific carotenoids (alpha-carotene, beta-carotene, beta-cryptoxanthin, lutein + zeaxanthin, and lycopene) and risk of colorectal cancer using the primary data from 11 cohort studies carried out in North America and Europe. Carotenoid intakes were estimated from food frequency questionnaires administered at baseline in each study. During 6-20 years of follow-up between 1980 and 2003, 7,885 incident cases of colorectal cancer were diagnosed among 702,647 participants. The authors calculated study-specific multivariate relative risks and then combined them using a random-effects model. In general, intakes of specific carotenoids were not associated with colorectal cancer risk. The pooled multivariate relative risks of colorectal cancer comparing the highest quintile of intake with the lowest ranged from 0.92 for lutein + zeaxanthin to 1.04 for lycopene; only for lutein + zeaxanthin intake was the result borderline statistically significant (95\% confidence interval: 0.84 , 1.00). The associations observed were generally similar across studies, for both sexes, and for colon cancer and rectal cancer. These pooled data did not suggest that carotenoids play an important role in the etiology of colorectal cancer.

carotenoids; cohort studies; colonic neoplasms; colorectal neoplasms; diet; meta-analysis; rectal neoplasms

Abbreviations: $\mathrm{Cl}$, confidence interval; $\mathrm{RR}$, relative risk.

Correspondence to Dr. Satu Männistö, Department of Health Promotion and Chronic Disease Prevention, National Public Health Institute, Mannerheimintie 166, 00300 Helsinki, Finland (e-mail: satu.mannisto @ktl.fi). 
Colorectal cancer is one of the most common incident and fatal malignancies worldwide (1), but up to 80 percent of cases may be preventable through dietary changes (2). Many substances in plant foods-for example, fiber, folate, and carotenoids - have been suggested to have anticarcinogenic capacity (3), but the epidemiologic evidence does not clearly support protection against colorectal cancer (4).

Carotenoids are red and yellow fat-soluble pigments found in many fruits and vegetables. They can be divided into those with and without vitamin A activity. The major carotenoids with vitamin A activity in human plasma are alpha-carotene, beta-carotene, and beta-cryptoxanthin, whereas the major carotenoids without vitamin A activity are lycopene and lutein + zeaxanthin (5). Carrots contain high amounts of alpha-carotene and beta-carotene. Beta-cryptoxanthin is found mainly in orange juice, oranges, and tangerines. Tomatoes contain high amounts of lycopene, whereas broccoli and spinach provide lutein + zeaxanthin and their isomers (5-8). Because of the difficulty involved in separating lutein and zeaxanthin in laboratory analyses, most food composition databases use a combined value for lutein + zeaxanthin intake $(6,8)$.

In case-control studies, the risks of colon and rectal cancer have generally been lower with increasing total carotenoid intake (9-12). Of the specific carotenoids evaluated, beta-carotene has been most extensively examined in epidemiologic studies, partly because of its abundance and the availability of food composition data (13). In most (14-17) but not all (10) case-control studies, higher intakes of betacarotene have been associated with a reduced risk of colon or rectal cancer. However, the results for beta-carotene intake have been inconsistent in cohort studies of colorectal cancer (18-20), in studies of precursor lesions for colorectal cancer (adenomas) (21-24), and in clinical trials of betacarotene supplementation $(25,26)$. Data on associations between intakes of other specific carotenoids and colon or rectal cancer risk also have been conflicting $(11,19,20$, 27-29).

To better understand the relation of specific dietary carotenoids (alpha-carotene, beta-carotene, beta-cryptoxanthin, lutein + zeaxanthin, and lycopene) to colorectal cancer risk, we analyzed the primary data from 11 large cohort studies carried out in North America and Europe. These studies, taken together, provided a wide range of carotenoid intakes and a large number of cases, which allowed for separate analyses by tumor site in the large bowel (proximal colon, distal colon, and rectum) and in subgroups of the study population.

\section{MATERIALS AND METHODS}

The Pooling Project of Prospective Studies of Diet and Cancer (The Pooling Project) is a collaborative project involving multiple cohort studies (30). For the carotenoidcolorectal-cancer analyses, we identified 11 cohort studies (table 1) (19, 20, 31-38) that met the following predefined criteria: at least 50 incident colorectal cancer cases; assessment of long-term dietary intake, including intake of the specific carotenoids; and a validation study of the dietary questionnaire or of a closely related instrument. The Advent- ist Health Study (39), the New York University Women's Health Study (40), and the Ormonie Dieta nella Eziologia dei Tumori (ORDET) Study (41), all included in other colorectal cancer analyses within the Pooling Project, were excluded from these analyses because the investigators did not assess intakes of the specific carotenoids. Each of the studies included here had been previously reviewed and approved by the review board of the institution at which the study was conducted.

Because the Cancer Prevention Study II Nutrition Cohort, the Netherlands Cohort Study on Diet and Cancer, and the New York State Cohort included both women and men, each of these studies was analyzed as containing two separate cohorts defined on the basis of sex. To take advantage of the more extensive dietary assessment completed in 1986, the cases and person-time accumulated in the Nurses' Health Study were divided into two groups for analysis (1980-1986 and 1986-2000); these cohorts are referred to as Nurses' Health Study (a) and Nurses' Health Study (b), respectively. The Canadian National Breast Screening Study and the Netherlands Cohort Study on Diet and Cancer were each analyzed as a case-cohort study (42) because the investigators in those studies processed questionnaires for only a random sample of the cohort to represent the person-time of the cohort and for all participants who were diagnosed with colorectal cancer during follow-up.

\section{Outcome ascertainment}

Colorectal cancer cases were ascertained in each study using follow-up questionnaires with subsequent medical record review $(33,37)$, linkage with a cancer registry $(20,31$, $32,34,43)$, or both $(19,35,36)$. In addition, some studies used linkage with a death registry $(19,20,31-33,35,36$, 38, 43).

\section{Dietary assessment}

Food consumption was assessed at baseline using a validated food frequency questionnaire developed for each study population (44-51). The number of food items on the questionnaires ranged from 45 for the New York State Cohort (48) to 276 in the Alpha-Tocopherol, Beta-Carotene Cancer Prevention Study (45). The food data were converted into daily nutrient intakes according to the software and food composition database used in each cohort study before they were sent to the Department of Nutrition at the Harvard School of Public Health (Boston, Massachusetts). Nutrient data were energy-adjusted according to the residual method (52) using predicted intakes of $2,100 \mathrm{kcal} /$ day in men and $1,600 \mathrm{kcal} /$ day in women. Mean energy intake ranged from $1,802 \mathrm{kcal} /$ day (Cancer Prevention Study II Nutrition Cohort) to 2,814 kcal/day (Alpha-Tocopherol, Beta-Carotene Cancer Prevention Study) in men and from 1,279 kcal/day (Breast Cancer Detection Demonstration Project) to 2,065 kcal/ day (Canadian National Breast Screening Study) in women (table 1).

In the validation analyses of the included cohort studies, the investigators generally did not examine specific 
TABLE 1. Characteristics of cohort studies included in a pooled analysis of energy-adjusted dietary carotenoid intake and colorectal cancer, Pooling Project of Prospective Studies of Diet and Cancer

\begin{tabular}{|c|c|c|c|c|c|c|c|c|c|}
\hline \multirow[b]{2}{*}{$\begin{array}{l}\text { Study and sex of } \\
\text { subjects (ref. no.) }\end{array}$} & \multirow[b]{2}{*}{$\begin{array}{l}\text { Follow-up } \\
\text { period }\end{array}$} & \multirow[b]{2}{*}{$\begin{array}{l}\text { Baseline } \\
\text { cohort } \\
\text { size (no.) }\end{array}$} & \multirow[b]{2}{*}{$\begin{array}{l}\text { No. of } \\
\text { cases }\end{array}$} & \multicolumn{6}{|c|}{ Mean dietary intake } \\
\hline & & & & $\begin{array}{l}\text { Energy } \\
\text { (kcal/day) }\end{array}$ & $\begin{array}{l}\text { Alpha- } \\
\text { carotene } \\
(\mu \mathrm{g} / \text { day })\end{array}$ & $\begin{array}{c}\text { Beta- } \\
\text { carotene } \\
(\mu \mathrm{g} / \text { day })\end{array}$ & $\begin{array}{c}\text { Beta- } \\
\text { cryptoxanthin } \\
(\mu \mathrm{g} / \text { day })\end{array}$ & $\begin{array}{l}\text { Lycopene } \\
(\mu \mathrm{g} / \text { day })\end{array}$ & $\begin{array}{l}\text { Lutein }+ \\
\text { zeaxanthin } \\
(\mu \mathrm{g} / \text { day })\end{array}$ \\
\hline $\begin{array}{l}\text { Alpha-Tocopherol, Beta-Carotene } \\
\text { Cancer Prevention Study (men) (19) }\end{array}$ & 1985-1999 & 26,987 & 321 & $2,814(768) *$ & $522(504)$ & $1,741(1,254)$ & $25(30)$ & $620(573)$ & $1,141(323)$ \\
\hline $\begin{array}{l}\text { Breast Cancer Detection } \\
\text { Demonstration Project (women) (35) }\end{array}$ & 1987-1999 & 41,987 & 436 & $1,279(527)$ & $532(577)$ & $3,401(2,999)$ & 98 (95) & $1,542(1,852)$ & $2,752(3,747)$ \\
\hline $\begin{array}{l}\text { Canadian National Breast } \\
\text { Screening Study (women) (20) }\end{array}$ & 1980-2000 & 49,613 & 612 & $2,065(650)$ & $991(821)$ & $4,633(2,949)$ & $80(58)$ & $8,909(8,998)$ & $3,046(3,090)$ \\
\hline \multicolumn{10}{|l|}{$\begin{array}{l}\text { Cancer Prevention Study II Nutrition } \\
\text { Cohort (36) }\end{array}$} \\
\hline Women & 1992-1999 & 74,046 & 479 & $1,362(476)$ & 388 (355) & $2,658(1,900)$ & $76(61)$ & $4,446(3,135)$ & $1,943(2,221)$ \\
\hline Men & 1992-1999 & 66,071 & 720 & $1,802(616)$ & $503(463)$ & $3,321(2,423)$ & $78(64)$ & $5,479(3,760)$ & $2,200(2,481)$ \\
\hline $\begin{array}{l}\text { Health Professionals Follow-up Study } \\
\text { (men) (33) }\end{array}$ & 1986-2000 & 47,766 & 597 & $1,986(619)$ & $978(1,030)$ & $5,159(3,583)$ & 88 (103) & $10,864(7,871)$ & $3,960(3,076)$ \\
\hline $\begin{array}{l}\text { lowa Women's Health Study } \\
\text { (women) (31) }\end{array}$ & 1986-2001 & 34,588 & 1,010 & $1,799(597)$ & 772 (824) & $4,526(3,162)$ & $74(72)$ & $4,181(4,257)$ & $2,794(2,823)$ \\
\hline \multicolumn{10}{|l|}{$\begin{array}{l}\text { Netherlands Cohort Study on Diet and } \\
\text { Cancer (34) }\end{array}$} \\
\hline Women & 1986-1993 & 62,412 & 501 & $1,689(397)$ & $687(586)$ & $2,901(1,542)$ & $205(173)$ & $1,302(1,890)$ & $2,440(1,027)$ \\
\hline Men & 1986-1993 & 58,279 & 646 & $2,162(501)$ & $679(528)$ & $2,937(1,450)$ & $151(160)$ & $1,043(1,547)$ & $2,541(1,116)$ \\
\hline \multicolumn{10}{|l|}{ New York State Cohort (32) } \\
\hline Women & 1980-1987 & 22,550 & 296 & $1,636(565)$ & $1,147(854)$ & $6,357(3,381)$ & $247(264)$ & $5,702(4,116)$ & $5,998(3,792)$ \\
\hline Men & $1980-1987$ & 30,363 & 492 & $2,132(790)$ & $1,173(867)$ & $6,393(3,457)$ & $216(274)$ & $7,281(4,750)$ & $6,034(3,500)$ \\
\hline \multicolumn{10}{|l|}{ Nurses' Health Study† (women) (33) } \\
\hline Nurses' Health Study (a) & 1980-1986 & 88,651 & 220 & $1,569(500)$ & $724(840)$ & $4,425(3,632)$ & $105(92)$ & $5,257(5,308)$ & $5,088(5,291)$ \\
\hline Nurses' Health Study (b) & 1986-2000 & $68,502 \ddagger$ & 648 & $1,770(524)$ & $765(637)$ & $4,273(2,403)$ & $62(62)$ & $9,646(6,140)$ & $3,531(2,553)$ \\
\hline $\begin{array}{l}\text { Swedish Mammography Cohort } \\
\text { (women) (38) }\end{array}$ & 1987-2003 & 60,950 & 706 & $1,585(445)$ & $743(753)$ & $2,843(2,142)$ & $373(424)$ & $1,102(1,066)$ & $1,269(913)$ \\
\hline Women's Health Study (women) (37) & 1993-2002 & 38,384 & 201 & $1,728(533)$ & $786(761)$ & $4,097(2,563)$ & $63(67)$ & $8,511(5,972)$ & $3,465(2,707)$ \\
\hline Total & & 702,647 & 7,885 & & & & & & \\
\hline Women & & $473,181(67 \%)$ & $5,109(65 \%)$ & & & & & & \\
\hline Men & & 229,466 (33\%) & $2,776(35 \%)$ & & & & & & \\
\hline
\end{tabular}

* Numbers in parentheses, standard deviation.

† The cases and person-time accumulated in the Nurses' Health Study (33) were divided into two groups for analysis (1980-1986 and 1986-2000); these cohorts are referred to as Nurses' Health Study (a) and Nurses' Health Study (b), respectively.

‡ These participants were also included in Nurses' Health Study (a) and are not included in the total baseline cohort size. 
carotenoids (44-51). The energy-adjusted and deattenuated correlations comparing the food frequency questionnaire with two 1 -week dietary records were over 0.60 for total carotenoid intake in the Health Professionals Follow-up Study (47) and the New York State Cohort (48). The Pearson energy-adjusted, deattenuated correlation coefficients between food frequency questionnaires and reference methods ranged from 0.30 to 0.58 for beta-carotene $(50,51,53)$. The correlation coefficients exceeded 0.50 for fruits, citrus fruits, and fruit juices and were between 0.09 and 0.62 for total vegetables and specific groups of vegetables $(45,49,51)$.

\section{Statistical methods}

After applying the exclusion criteria used in each study, we further excluded participants if they had reported $\log _{\mathrm{e}^{-}}$ transformed energy intakes beyond three standard deviations from the study-specific $\log _{\mathrm{e}}$-transformed mean energy intake or if they had reported a history of cancer (except nonmelanoma skin cancer) at baseline.

We analyzed associations with specific carotenoids by quintiles of intake. For the Canadian National Breast Screening Study and the Netherlands Cohort Study on Diet and Cancer, study-specific quintiles were assigned on the basis of distributions in the subcohort; for the remaining studies, study-specific quintiles were based on the distributions in the baseline cohort. In further analyses, we defined categories using cutpoints based on identical absolute intakes across studies. Two-sided 95 percent confidence intervals and $p$ values were calculated. To calculate the $p$ value for the test for trend across categories of intake, we assigned participants the median value of their category of intake and entered this variable as a continuous term in the regression model.

Each study was analyzed using a Cox proportional hazards model (54). Person-years of follow-up were calculated from the date on which the baseline questionnaire was returned to the date of colorectal cancer diagnosis, the date of death, or the end of follow-up, whichever came first. In the analyses, we simultaneously accounted for age, calendar time, and time since entry into the study by including age at baseline in years and the year of the baseline questionnaire as stratification variables and by treating follow-up time as the time scale. Relative risks and their 95 percent confidence intervals were estimated using SAS PROC PHREG (55).

Relative risks were adjusted for age, education, body mass index (weight $(\mathrm{kg}) /$ height $(\mathrm{m})^{2}$ ), height, alcohol consumption, smoking habits, family history of colorectal cancer, physical activity, use of nonsteroidal antiinflammatory drugs, energy intake, red meat intake, total milk intake, folate intake from food, and use of multivitamin supplements (see table 2 for the categories used). For women, the relative risks were also adjusted for history of oral contraceptive use and postmenopausal hormone use. We had no missing data for any nutrients. An indicator variable for missing responses for measured covariates within a study was created when needed. For each covariate, data generally were missing for less than 5 percent of the participants in each study (30).

We used a random-effects model (56) to combine the study-specific $\log _{\mathrm{e}}$ relative risks, which were weighted by the inverse of their variance. We tested for heterogeneity among studies using the $Q$ statistic $(56,57)$ and for variation in relative risks by sex, smoking status, oral contraceptive use, postmenopausal hormone use, multivitamin supplement use, meat consumption, and polyunsaturated fatty acid intake using meta-regression models (58).

We evaluated whether associations differed among subsites of colorectal cancer using a Wald test to test the null hypothesis of no difference among the $\log _{\mathrm{e}}$ relative risks $(59,60)$. For these analyses, we fitted separate Cox proportional hazards models for each tumor site. Colon cancers were considered those tumors located in the area from the cecum through the sigmoid colon. Tumors in the area from the cecum to the splenic flexure were considered proximal colon cancers. The remaining tumors in the colon were defined as distal colon cancers. Rectal cancers included tumors located in the rectum and the rectosigmoid junction. Persons with cancer at multiple sites or with missing data on cancer site were included in the colorectal cancer analyses but were excluded from the specific tumor site analyses.

\section{RESULTS}

The pooled data included 7,885 incident colorectal cancer cases (5,109 in women and 2,776 in men) diagnosed among 702,647 participants who were followed for 6-20 years across studies (table 1). The follow-up rates for these studies generally exceeded 90 percent. Reported carotenoid intakes varied across the cohorts (table 1). The New York State Cohort had the highest reported intakes, with two exceptions: Lycopene intake was highest in the Health Professionals Follow-up Study, and beta-cryptoxanthin intake was highest in the Swedish Mammography Cohort. The lowest reported intakes were in the Alpha-Tocopherol, Beta-Carotene Cancer Prevention Study, with one exception: Alpha-carotene intake was lowest in the Cancer Prevention Study II Nutrition Cohort.

In the age-adjusted analyses, the pooled relative risk of colorectal cancer comparing the highest quintile of intake with the lowest ranged from 0.89 for lutein + zeaxanthin to 1.01 for lycopene (table 2). Most of the age-adjusted results were attenuated after adjustment for confounding factors related to colorectal cancer risk. In the multivariate analyses, the relative risks for colorectal cancer were less than unity in each of the four higher lutein + zeaxanthin quintiles as compared with the lowest quintile of intake (highest quintile vs. lowest: pooled relative risk $(\mathrm{RR})=0.92,95$ percent confidence interval (CI): 0.84, 1.00; test for trend: $p=0.08$ ). The study-specific relative risk for the highest quintile of lutein + zeaxanthin intake versus the lowest ranged from 0.70 to 1.18 across studies (test for between-studies heterogeneity: $p=0.67$ ); a significant inverse association was found only among women in the Cancer Prevention Study II Nutrition Cohort ( $R R=0.70,95$ percent CI: 0.51, 0.96). For beta-carotene intake, statistically significant betweenstudies heterogeneity was found for quintile 5 (table 2). The study-specific relative risks ranged from 0.62 to 1.44 , with statistically significant associations being observed only in the Canadian National Breast Screening Study 
TABLE 2. Pooled relative risk of colorectal cancer by quintile of dietary carotenoid intake, Pooling Project of Prospective Studies of Diet and Cancer*

\begin{tabular}{|c|c|c|c|c|c|c|c|c|c|c|c|}
\hline \multirow[b]{2}{*}{ Carotenoid } & \multicolumn{2}{|c|}{ Quintile 2} & \multicolumn{2}{|c|}{ Quintile 3} & \multicolumn{2}{|c|}{ Quintile 4} & \multicolumn{2}{|c|}{ Quintile 5} & \multicolumn{3}{|c|}{$p$ value } \\
\hline & $\mathrm{RR} \dagger$ & $95 \% \mathrm{Cl} \dagger$ & $\mathrm{RR}$ & $95 \% \mathrm{Cl}$ & $\mathrm{RR}$ & $95 \% \mathrm{Cl}$ & $\mathrm{RR}$ & $95 \% \mathrm{Cl}$ & $\begin{array}{l}\text { Test } \\
\text { for } \\
\text { trend }\end{array}$ & $\begin{array}{c}\text { Test for } \\
\text { between- } \\
\text { studies } \\
\text { heterogeneity } \\
\text { for quintile } 5\end{array}$ & $\begin{array}{c}\text { Test for } \\
\text { between- } \\
\text { studies } \\
\text { heterogeneity } \\
\text { due to sex } \\
\text { for quintile } 5\end{array}$ \\
\hline \multicolumn{12}{|l|}{ Alpha-carotene } \\
\hline Age-adjusted & 1.01 & $0.93,1.08$ & 1.05 & $0.97,1.12$ & 0.99 & $0.90,1.09$ & 0.94 & $0.87,1.02$ & 0.13 & 0.37 & 0.88 \\
\hline \multicolumn{12}{|l|}{ Beta-carotene } \\
\hline Age-adjusted & 0.97 & $0.90,1.04$ & 0.95 & $0.86,1.05$ & 0.91 & $0.80,1.03$ & 0.90 & $0.81,0.99$ & 0.03 & 0.03 & 0.60 \\
\hline Multivariate $\ddagger$ & 0.99 & $0.92,1.07$ & 0.99 & $0.89,1.11$ & 0.95 & $0.82,1.10$ & 0.96 & $0.85,1.09$ & 0.39 & 0.01 & 0.54 \\
\hline \multicolumn{12}{|c|}{ Beta-cryptoxanthin } \\
\hline Age-adjusted & 0.96 & $0.88,1.04$ & 0.93 & $0.86,1.00$ & 0.90 & $0.83,0.96$ & 0.93 & $0.86,1.01$ & 0.12 & 0.29 & 0.65 \\
\hline Multivariate $\neq$ & 1.02 & $0.94,1.09$ & 0.94 & $0.87,1.02$ & 0.94 & $0.87,1.02$ & 1.04 & $0.96,1.12$ & 0.60 & 0.83 & 0.51 \\
\hline \multicolumn{12}{|c|}{ Lutein + zeaxanthin } \\
\hline Age-adjusted & 0.90 & $0.84,0.97$ & 0.89 & $0.83,0.96$ & 0.84 & $0.78,0.90$ & 0.89 & $0.82,0.95$ & 0.01 & 0.61 & 0.64 \\
\hline Multivariate $\ddagger$ & 0.91 & $0.85,0.98$ & 0.91 & $0.84,0.98$ & 0.86 & $0.79,0.93$ & 0.92 & $0.84,1.00$ & 0.08 & 0.67 & 0.81 \\
\hline
\end{tabular}

* Quintile 1 was the reference category $(\mathrm{RR}=1.00)$.

† RR, relative risk; $\mathrm{Cl}$, confidence interval.

$\ddagger$ Adjusted for education (less than high school, completion of high school, or more than high school), body mass index (weight (kg)/height ( $\mathrm{m})^{2}$; $<23,23-<25,25-<30$, or $\left.\geq 30 \mathrm{~kg} / \mathrm{m}^{2}\right)$, height $(<1.60,1.60-<1.65,1.65-<1.70,1.70-<1.75$, or $\geq 1.75 \mathrm{~m}$ for women and $<1.70,1.70-<1.75$, $1.75-<1.80,1.80-<1.85$, or $\geq 1.85 \mathrm{~m}$ for men), alcohol consumption $(0,>0-<5,5-<15,15-<30$, or $\geq 30$ g/day), smoking (never smoker, past smoker ( $<20,20-<40$, or $\geq 40$ years' duration), or current smoker ( $<25$ cigarettes/day and $<40$ years, $<25$ cigarettes/day and $\geq 40$ years, $\geq 25$ cigarettes/day and $<40$ years, or $\geq 25$ cigarettes/day and $\geq 40$ years)), family history of colorectal cancer (no/yes), degree of physical activity (low, medium, or high), use of nonsteroidal antiinflammatory drugs (no/yes), energy intake (continuous), red meat intake (quartiles), total milk intake (quartiles), folate intake from food (quintiles), and use of multivitamins (categories: "no," "yes, $<6$ times/week," "yes, $\geq 6$ times/week," or "yes, but missing dose" for the Breast Cancer Detection Demonstration Project (35), the Heath Professionals Follow-up Study (33), the lowa Women's Health Study (31), Nurses' Health Study (a) and (b) (33), and the Women's Health Study (37); no/yes for the Alpha-Tocopherol, Beta-Carotene Cancer Prevention Study (19), the Cancer Prevention Study II Nutrition Cohort (36), the Netherlands Cohort Study on Diet and Cancer (34), and the New York State Cohort (32)). For women, relative risks were also adjusted for history of oral contraceptive use (ever/never) and use of postmenopausal hormone therapy (premenopausal, dubious menopausal status, postmenopausal ever user, postmenopausal never user, or postmenopausal but missing data on hormone therapy).

$(\mathrm{RR}=0.62,95$ percent $\mathrm{CI}: 0.46,0.84)$ and among men in the Cancer Prevention Study II Nutrition Cohort $(\mathrm{RR}=$ $0.77,95$ percent $\mathrm{CI}: 0.60,0.98)$. The $p$ value from the trend test for between-studies heterogeneity showed results consistent with those observed for the highest quintile for each carotenoid, with the exception of alpha-carotene, for which the test for heterogeneity for trend was of borderline statistical significance.

Because beta-carotene is present primarily in fruits and vegetables, we examined whether the association between beta-carotene intake and colorectal cancer risk differed by the number of fruit and vegetable items on the food frequency questionnaire in each study, but there was no difference by the number of items $(p=0.78)$. In further analyses for lycopene, no association was observed between lycopene intake and colorectal cancer risk when the models included only those cohorts (Breast Cancer Detection Demonstra- tion Project, Cancer Prevention Study II Nutrition Cohort, Health Professionals Follow-up Study, Iowa Women's Health Study, Nurses' Health Study (b), and Women's Health Study) for which tomato-sauce consumption (a major source of bioavailable lycopene in many populations) was included in the food frequency questionnaire (highest quintile vs. lowest: pooled $\mathrm{RR}=1.08,95$ percent $\mathrm{CI}$ : $0.98,1.20$ ). None of the associations for the specific carotenoids was modified by sex in the age-adjusted or multivariate analyses. The result for beta-carotene was also similar after exclusion of the Alpha-Tocopherol, Beta-Carotene Cancer Prevention Study and the Women's Health Study, which both had betacarotene interventions. Further adjustment for either dietary folate or dietary fiber did not materially change the results (data not shown).

Results for each carotenoid were not significantly different by period of follow-up. When cases diagnosed 
during the first 5 years of follow-up were excluded from the analyses $(3,201$ cases excluded), the result for each carotenoid was not materially different from the result including all cases. For example, in these analyses, the pooled multivariate relative risk of colorectal cancer for lutein + zeaxanthin intake was 0.92 (95 percent CI: 0.82, 1.04; highest quintile vs. lowest); for cases diagnosed within the first 5 years after baseline, the pooled multivariate relative risk for the same comparison was 0.91 (95 percent CI: 0.80, 1.05).

Because of earlier findings that the association between carotenoid intake and colon cancer risk might vary by age (27), we also stratified our results by age at case diagnosis: less than 65 years ( $n=2,934$ cases; 37 percent) versus 65 years or older ( $n=4,951$ cases; 63 percent). For alphacarotene, beta-cryptoxanthin, lycopene, and lutein + zeaxanthin, there was no more than a 10 percent difference in the relative risks comparing the highest quintile of intake with the lowest for each age group in comparison with the overall result shown in table 2. For beta-carotene, the associations for the two age groups were significantly different ( $p$ for difference $=0.02$ ), although the relative risks for both age groups were nonsignificant; the pooled multivariate relative risks (highest quintile vs. lowest) were 1.08 (95 percent CI: 0.91, 1.28; $p$ for between-studies heterogeneity = 0.09 ) among persons younger than age 65 years and 0.90 (95 percent CI, 0.79, 1.02; $p$ for between-studies heterogeneity $=0.12$ ) among persons aged 65 years or older. The Nurses' Health Study (a) was excluded from the analyses of participants aged 65 years or older because only one case was older than 65 years of age at diagnosis.

Results for each carotenoid were not significantly different between users and nonusers of multivitamins ( $p$ for interaction $>0.1$ ). Among nonusers of multivitamin supplements (4,631 cases; 59 percent of the cases), the pooled multivariate relative risks of colorectal cancer for the highest quintile compared with the lowest were 1.06 (95 percent CI: $0.95,1.17$ ) for alpha-carotene, 1.00 (95 percent CI: $0.90,1.12$ ) for beta-carotene, 1.03 (95 percent CI: 0.93, 1.14) for betacryptoxanthin, 1.10 (95 percent CI: 1.00, 1.21) for lycopene, and 0.90 (95 percent CI: $0.80,1.00)$ for lutein + zeaxanthin. The Canadian National Breast Screening Study and the Swedish Mammography Cohort were excluded from these analyses because the investigators did not have data on multivitamin use. Furthermore, the associations between intake of each carotenoid and colorectal cancer risk were not modified by smoking status (never, past, or current smoker), oral contraceptive use (ever vs. never), postmenopausal hormone use (never, past, or current use, among postmenopausal women only), red meat consumption (tertiles), alcohol intake ( $<5 \mathrm{~g} /$ day, $5-<15 \mathrm{~g} /$ day, or $\geq 15 \mathrm{~g} /$ day), and polyunsaturated fatty acid intake (tertiles; data not shown).

We also categorized participants into deciles to examine more extreme contrasts in intakes of each carotenoid. For lutein + zeaxanthin, no reduction in risk was observed in the second decile of intake, whereas the risks were below 1 (but not all statistically significant) in the upper deciles (highest decile of intake vs. lowest: pooled multivariate $\mathrm{RR}=0.93$, 95 percent CI: $0.83,1.04)$. For lycopene, the association became slightly more positive among all studies (highest decile vs. lowest: pooled multivariate $\mathrm{RR}=1.10,95$ percent CI: $0.99,1.22)$. This result was similar when we restricted the analysis to those studies in which tomato sauce consumption was included on the food frequency questionnaire.

We further analyzed the intake of lutein + zeaxanthin using identical categories defined by absolute intake cutpoints across studies. Compared with lutein + zeaxanthin intake of $<1,000 \mu \mathrm{g} / \mathrm{day}$, the pooled multivariate relative risks of colorectal cancer were 0.96 (95 percent CI: 0.88, 1.03) for lutein + zeaxanthin intake of $1,000-<2,000 \mu \mathrm{g} /$ day, 0.89 (95 percent CI: 0.77, 1.03) for intake of 2,000 $<3,000 \mu \mathrm{g} /$ day, 0.87 (95 percent CI: $0.74,1.02$ ) for intake of $3,000-<4,000 \mu \mathrm{g} / \mathrm{day}$, and 0.87 (95 percent CI: 0.78, 0.98) for intake of $\geq 4,000 \mu \mathrm{g} / \mathrm{day}$ ( $p$ for trend $<0.01$ ). A lutein + zeaxanthin intake of $2,000 \mu \mathrm{g}$ is equivalent to the amount in approximately $100 \mathrm{~g}$ of broccoli (8). The Alpha-Tocopherol, Beta-Carotene Cancer Prevention Study was excluded from the three upper categories of lutein + zeaxanthin intake because fewer than 0.5 percent of the participants had intakes in those categories.

We examined associations between specific carotenoid intakes and colorectal cancer risk separately for cancers of the colon (number of cases $=5,581$ ), proximal colon (number of cases $=2,924)$, distal colon (cases $=2,211$ ), and rectum (cases $=2,139)$ (table 3 ). For each carotenoid, associations were not significantly different between colon and rectal cancers or between proximal and distal colon cancers (except for alpha-carotene).

\section{DISCUSSION}

In this pooled analysis, in general, no association between intake of specific carotenoids and colorectal cancer risk was found. However, a high intake of lutein + zeaxanthin was nonlinearly associated with a slightly lower risk of colorectal cancer in analyses using either study-specific quintiles or identical absolute intake cutpoints. The possible inclusion of undiagnosed early cases of colorectal cancer in our study is unlikely to have biased our findings, because the results were quite similar after we excluded cases diagnosed during the first 5 years of follow-up. For each carotenoid, associations with colon cancer and rectal cancer were similar.

Carotenoids have been hypothesized to decrease the risk of gastrointestinal cancer because of their antioxidant properties, which protect lipid membranes from damage by free radicals (61). Patients with adenomatous polyps (precursor lesions of colorectal cancer) have lower concentrations of specific carotenoids in their colonic mucosa compared with controls, despite having similar serum concentrations (62). Colorectal adenomatous tissue also has been shown to have lower concentrations of specific carotenoids compared with noninvolved mucosal tissue (63). These findings support the suggestion that oxidative stress may be higher in the colonic mucosa of patients with adenomatous polyps. Lutein and zeaxanthin are more effective than beta-carotene as scavengers against oxygen radicals. Beta-carotene, however, resides in the inner part of the cell membrane, whereas lutein and zeaxanthin, with less hydrophobic structures, react with free radicals in membranes during the aqueous phase, 
TABLE 3. Pooled multivariate relative risk* of colorectal cancer according to carotenoid intake and tumor subsite $\dagger$, Pooling Project of Prospective Studies of Diet and Cancerł

\begin{tabular}{|c|c|c|c|c|c|c|c|c|c|c|c|c|}
\hline \multirow[b]{2}{*}{$\begin{array}{l}\text { Carotenoid and } \\
\text { subsite }\end{array}$} & \multicolumn{2}{|c|}{ Quintile 2} & \multicolumn{2}{|c|}{ Quintile 3} & \multicolumn{2}{|c|}{ Quintile 4} & \multicolumn{2}{|c|}{ Quintile 5} & \multicolumn{4}{|c|}{$p$ value } \\
\hline & $\mathrm{RR} \S$ & $95 \% \mathrm{Cl} \S$ & $\mathrm{RR}$ & $95 \% \mathrm{Cl}$ & $\mathrm{RR}$ & $95 \% \mathrm{Cl}$ & $\mathrm{RR}$ & $95 \% \mathrm{Cl}$ & $\begin{array}{l}\text { Test } \\
\text { for } \\
\text { trend }\end{array}$ & $\begin{array}{l}\text { Test for } \\
\text { between- } \\
\text { studies } \\
\text { heterogeneity } \\
\text { for quintile } 5\end{array}$ & $\begin{array}{l}\text { Test for common } \\
\text { effects between } \\
\text { colon and } \\
\text { rectal cancer } \\
\text { for quintile } 5\end{array}$ & $\begin{array}{l}\text { Test for common } \\
\text { effects between } \\
\text { proximal and } \\
\text { distal colon cancer } \\
\text { for quintile } 5\end{array}$ \\
\hline \multicolumn{13}{|l|}{ Alpha-carotene } \\
\hline Colon & 1.03 & $0.94,1.12$ & 1.06 & $0.97,1.16$ & 1.01 & $0.89,1.14$ & 0.99 & $0.89,1.10$ & 0.52 & 0.18 & & \\
\hline Proximal colon & 1.08 & $0.96,1.22$ & 1.12 & $0.99,1.26$ & 1.08 & $0.93,1.25$ & 1.09 & $0.95,1.25$ & 0.36 & 0.34 & & \\
\hline Distal colon & 0.94 & $0.82,1.08$ & 1.01 & $0.88,1.17$ & 0.93 & $0.77,1.13$ & 0.86 & $0.72,1.03$ & 0.12 & 0.15 & & \\
\hline Rectum & 1.01 & $0.87,1.16$ & 1.16 & $1.01,1.33$ & 1.11 & $0.96,1.28$ & 1.06 & $0.91,1.23$ & 0.70 & 0.79 & 0.45 & 0.04 \\
\hline \multicolumn{13}{|l|}{ Beta-carotene } \\
\hline Colon & 0.95 & $0.85,1.05$ & 0.98 & $0.86,1.12$ & 0.90 & $0.76,1.05$ & 0.92 & $0.79,1.08$ & 0.24 & 0.001 & & \\
\hline Proximal colon & 0.92 & $0.82,1.04$ & 1.02 & $0.88,1.18$ & 0.96 & $0.82,1.13$ & 1.02 & $0.85,1.24$ & 0.56 & 0.02 & & \\
\hline Distal colon & 0.98 & $0.82,1.16$ & 0.96 & $0.82,1.11$ & 0.81 & $0.64,1.03$ & 0.81 & $0.66,0.98$ & 0.02 & 0.08 & & \\
\hline Rectum & 1.12 & $0.97,1.29$ & 1.04 & $0.90,1.21$ & 1.14 & $0.98,1.33$ & 1.11 & $0.93,1.32$ & 0.56 & 0.26 & 0.13 & 0.09 \\
\hline \multicolumn{13}{|l|}{ Beta-cryptoxanthin } \\
\hline Colon & 0.99 & $0.90,1.09$ & 0.98 & $0.90,1.07$ & 0.92 & $0.84,1.01$ & 0.99 & $0.90,1.08$ & 0.59 & 0.78 & & \\
\hline Proximal colon & 0.98 & $0.87,1.10$ & 0.97 & $0.86,1.09$ & 0.90 & $0.80,1.02$ & 0.95 & $0.83,1.08$ & 0.17 & 0.81 & & \\
\hline Distal colon & 1.02 & $0.87,1.20$ & 1.04 & $0.90,1.20$ & 0.97 & $0.81,1.15$ & 1.02 & $0.88,1.19$ & 0.80 & 0.52 & & \\
\hline Rectum & 0.95 & $0.79,1.13$ & 0.94 & $0.81,1.08$ & 0.96 & $0.83,1.11$ & 1.01 & $0.87,1.17$ & 0.88 & 0.60 & 0.79 & 0.44 \\
\hline \multicolumn{13}{|l|}{ Lycopene } \\
\hline Colon & 1.00 & $0.92,1.08$ & 0.91 & $0.82,1.01$ & 0.92 & $0.84,1.00$ & 1.02 & $0.93,1.11$ & 0.74 & 0.83 & & \\
\hline Proximal colon & 1.00 & $0.89,1.13$ & 0.93 & $0.82,1.06$ & 0.94 & $0.83,1.06$ & 1.04 & $0.92,1.18$ & 0.29 & 0.38 & & \\
\hline Distal colon & 1.02 & $0.89,1.18$ & 0.87 & $0.76,1.00$ & 0.92 & $0.80,1.05$ & 0.99 & $0.86,1.14$ & 0.68 & 1.00 & & \\
\hline Rectum & 1.12 & $0.98,1.29$ & 1.08 & $0.92,1.25$ & 1.06 & $0.92,1.23$ & 1.16 & $1.00,1.34$ & 0.50 & 0.48 & 0.16 & 0.60 \\
\hline \multicolumn{13}{|c|}{ Lutein + zeaxanthin } \\
\hline Colon & 0.93 & $0.85,1.01$ & 0.91 & $0.83,0.99$ & 0.87 & $0.79,0.95$ & 0.93 & $0.85,1.03$ & 0.28 & 0.63 & & \\
\hline Proximal colon & 0.91 & $0.79,1.04$ & 0.92 & $0.81,1.03$ & 0.93 & $0.82,1.05$ & 0.96 & $0.84,1.10$ & 0.69 & 0.70 & & \\
\hline Distal colon & 0.99 & $0.87,1.13$ & 0.92 & $0.80,1.06$ & 0.82 & $0.70,0.95$ & 0.89 & $0.76,1.04$ & 0.09 & 0.89 & & \\
\hline Rectum & 0.88 & $0.76,1.01$ & 0.91 & $0.79,1.05$ & 0.85 & $0.73,0.98$ & 0.91 & $0.78,1.07$ & 0.30 & 0.99 & 0.80 & 0.46 \\
\hline
\end{tabular}

* Adjusted for education (less than high school, completion of high school, or more than high school), body mass index (weight $(\mathrm{kg}) / \mathrm{height}(\mathrm{m})^{2} ;<23,23-<25,25-<30$, or $\left.\geq 30 \mathrm{~kg} / \mathrm{m}^{2}\right)$,

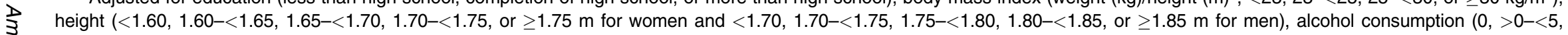
$5-<15,15-<30$, or $\geq 30 \mathrm{~g} /$ day), smoking (never smoker, past smoker ( $<20,20-<40$, or $\geq 40$ years' duration), or current smoker ( $<25$ cigarettes/day and $<40$ years, $<25$ cigarettes/day and $\geq 40$ years, $\geq 25$ cigarettes/day and $<40$ years, or $\geq 25$ cigarettes/day and $>40$ years)), family history of colorectal cancer (no/yes), degree of physical activity (low, medium, or high), use of nonsteroidal antiinflammatory drugs (no/yes), energy intake (continuous), red meat intake (quartiles), total milk intake (quartiles), folate intake from food (quintiles), and use of multivitamins (categories: "no," "yes, $<6$ times/week," "yes, $\geq 6$ times/week," or "yes, but missing dose" for the Breast Cancer Detection Demonstration Project (35), the Heath Professionals Follow-up Study (33), the lowa Women's Health Study (31), Nurses' Health Study (a) and (b) (33), and the Women's Health Study (37); no/yes for the Alpha-Tocopherol, Beta-Carotene Cancer Prevention Study (19), the Cancer Prevention Study II Nutrition Cohort (36), the Netherlands Cohort Study on Diet and Cancer (34), and the New York State Cohort (32)). For women, relative risks were also adjusted for history of oral contraceptive use (ever/never) and use of postmenopausal hormone therapy (premenopausal, dubious menopausal status, postmenopausal ever user, postmenopausal never user, or postmenopausal but missing data on hormone therapy).

t Colon cancers were considered those tumors located in the area from the cecum through the sigmoid colon. Tumors in the area from the cecum to the splenic flexure were considered proximal colon cancers, and the remaining tumors in the colon were defined as distal colon cancers. Rectal cancers included tumors located in the rectum and the rectosigmoid junction. Numbers of cases by subsite: proximal colon, $n=2,924$; distal colon, $n=2,211$; rectum, $n=2,139$.

‡ Quintile 1 was the reference category $(R R=1.00)$.

$\S \mathrm{RR}$, relative risk; $\mathrm{Cl}$, confidence interval. 
thereby increasing membrane integrity (64). Carotenoids may also regulate cell growth and cell proliferation, modulate gene expression, and affect the immune response (21, $65,66)$.

Several observational studies have previously examined the association between carotenoid intake and colorectal cancer risk. In a cohort of residents of a retirement community (a study that did not meet our inclusion criteria) in which there were 97 colorectal cancer cases in women and 105 cases in men, intake of beta-carotene was not associated with colorectal cancer risk; associations with other carotenoids were not examined (18). Inverse associations have been reported most consistently for lutein + zeaxanthin, alpha-carotene, and beta-carotene in case-control studies $(11,14-17,27-29)$, especially among studies with a low average level of carotenoid intake $(27,29)$. Our results also suggest that colorectal cancer risk was elevated only with very low lutein + zeaxanthin intakes.

A recent case-control study from Canada found that the inverse association between lutein + zeaxanthin intake and colon cancer risk was limited to women with high intakes of long-chain polyunsaturated fatty acids (66). In our study, polyunsaturated fatty acid intake did not modify the association between lutein + zeaxanthin intake and colorectal cancer risk. The Canadian study also showed that associations for some of the carotenoids varied by smoking status; the risk of colon cancer was lower with higher beta-carotene intake in never smokers and with higher lycopene intake in smokers. In a US multicenter prevention trial, smoking and alcohol consumption modified the effect of beta-carotene supplementation on the risk of colorectal adenoma recurrence (24). Our result for each carotenoid was not modified by smoking or alcohol drinking. In contrast to our results showing no difference in the association for lutein + zeaxanthin by age at diagnosis, a large US case-control study found the strongest inverse association between lutein intake and colon cancer risk among persons younger than age 65 years (27). The authors of that study speculated that younger participants could recall their diets more accurately than older participants. However, a recent validation study comparing a food frequency questionnaire and a 3-day diet record found that men older than 50 years reported total carotenoid intake more accurately than did younger men, whereas women reported carotenoid intakes with similar accuracy in all age groups (67). Furthermore, cancers diagnosed at younger ages are suggested to have a stronger genetic basis, while cancers diagnosed at older ages are believed to be more related to environmental influences (68).

In studies using prospectively collected blood samples, no association has been observed between blood levels of betacarotene $(19,69)$ and colorectal cancer risk. Additionally, large controlled trials have not found reduced risks of colorectal cancer among study subjects assigned to beta-carotene supplementation $(25,26,70)$, which is in agreement with our current results.

A strength of our study was the large compilation of data from multiple cohort studies, such that we could examine associations between carotenoid intakes and colorectal cancer risk with greater statistical power than was possible in any of the individual studies included in the analysis (30).
These pooled data facilitated analyses by different age groups, smoking groups, and tumor sites of the large bowel. Because the analyses were limited to prospective cohort studies, recall and selection biases were minimized. However, because the Pooling Project was initiated retrospectively, each of these cohort studies was planned independently, and numerous characteristics-such as the age range of the participants, the covariates measured, and the food frequency questionnaire used-differed across studies. However, in our pooled analyses, we standardized the categorizations of the dietary variables and covariates across studies to minimize potential sources of heterogeneity. In addition, for each carotenoid, except beta-carotene, there was no statistically significant heterogeneity between studies, suggesting that the differences in relative risk among the cohorts were compatible with random variation.

A limitation of our study concerns the assessment of intakes of specific carotenoids. We only had a single measure of carotenoid intake at baseline and were not able to investigate carotenoid intakes at younger ages or changes in carotenoid intake during follow-up. There also may have been variation in the carotenoid values in the different nutrient databases used across the studies. Furthermore, because fruits and vegetables contain many compounds that may decrease cancer risk (71), an association with a specific carotenoid may merely be a marker of one or more other compounds present in fruits and vegetables-for example, folate, isothiocyanate, and chlorophyll in green vegetables (72-74). Although we adjusted for intake of folate and for multivitamin use, it is possible that other substances in fruits and vegetables are primarily responsible for the associations observed for lutein + zeaxanthin, beta-carotene, and lycopene. The association between lutein + zeaxanthin intake and colorectal cancer risk remained similar after additional adjustment for total intake of vegetables, the main sources of lutein + zeaxanthin (data not shown). We also could not correct our results for measurement error, because carotenoid intakes were not evaluated in most of the validation analyses carried out for these cohort studies. Furthermore, we were not able to account for colorectal cancer screening in our analyses, because those data were not available in most of our studies. It may be that persons who are screened for colorectal cancer are more likely to adhere to a healthier diet and have higher carotenoid intakes than persons who are not screened for colorectal cancer.

In summary, these pooled multivariate data do not support an important association between intakes of specific carotenoids (alpha-carotene, beta-carotene, beta-cryptoxanthin, lutein + zeaxanthin, and lycopene) and colorectal cancer risk.

\section{ACKNOWLEDGMENTS}

This study was supported by research grants CA55075 and CA78548 from the National Cancer Institute, by US Public Health Service contracts N01 CN45165 and N01 CN45035 from the National Cancer Institute, and by the 
National Colorectal Cancer Research Alliance. Additional support was provided by research grants from the Juho Vainio Foundation (2005), the Paulo Foundation (2005), and the Academy of Finland (grant 213829).

The authors thank Christine Rivera for statistical expertise and Elizabeth Fisher and Victoria Chin for technical assistance.

Conflict of interest: none declared.

\section{REFERENCES}

1. Stewart BW, Kleihues P. World cancer report. Lyon, France: International Agency for Research on Cancer, 2003:1-19.

2. Cummings JH, Bingham SA. Diet and the prevention of cancer. BMJ 1998;317:1636-40.

3. Potter JD, Steinmetz K. Vegetables, fruit and phytoestrogens as preventive agents. IARC Sci Publ 1996;(139):61-90.

4. World Health Organization. Diet, nutrition and the prevention of chronic diseases. Geneva, Switzerland: World Health Organization, 2003.

5. Chug-Ahuja JK, Holden JM, Forman MR, et al. The development and application of a carotenoid database for fruits, vegetables, and selected multicomponent foods. J Am Diet Assoc 1993;93:318-23.

6. Mangels AR, Holden JM, Beecher GR, et al. Carotenoid content of fruits and vegetables: an evaluation of analytic data. J Am Diet Assoc 1993;93:284-96.

7. Goldbohm RA, Brants HAM, Hulshof KFAM, et al. The contribution of various foods to intake of vitamin A and carotenoids in the Netherlands. Int J Vitam Nutr Res 1998;68: 378-83.

8. Holden JM, Eldridge AL, Beecher GR, et al. Carotenoid content of U.S. foods: an update of the database. J Food Compos Anal 1999;12:169-96.

9. Freudenheim JL, Graham S, Marshall JR, et al. A case-control study of diet and rectal cancer in Western New York. Am J Epidemiol 1990;131:612-24.

10. Ghadirian P, Lacroix A, Maisonneuve P, et al. Nutritional factors and colon carcinoma: a case-control study involving French Canadians in Montreal, Quebec, Canada. Cancer 1997; 80:858-64.

11. Levi F, Pasche C, Lucchini F, et al. Selected micronutrients and colorectal cancer: a case-control study from the canton of Vaud, Switzerland. Eur J Cancer 2000;36:2115-19.

12. Chiu BC, Ji BT, Dai Q, et al. Dietary factors and risk of colon cancer in Shanghai, China. Cancer Epidemiol Biomarkers Prev 2003;12:201-8.

13. Vainio H, Rautalahti M. An international evaluation of the cancer preventive potential of carotenoids. Cancer Epidemiol Biomarkers Prev 1998;7:725-8.

14. Lee HP, Gourley L, Duffy SW, et al. Colorectal cancer and diet in an Asian population - a case-control study among Singapore Chinese. Int J Cancer 1989;43:1007-16.

15. Zaridze D, Filipchenko V, Kustov V, et al. Diet and colorectal cancer: results of two case-control studies in Russia. Eur J Cancer 1992;29A:112-15.

16. Ferraroni M, La Vecchia C, D'Avanzo B, et al. Selected micronutrient intake and the risk of colorectal cancer. Br J Cancer 1994;70:1150-5.

17. Franceschi S. Nutrients and food groups and large bowel cancer in Europe. Eur J Cancer Prev 1999;8(suppl 1):S49-52.

18. Shibata A, Paganini-Hill A, Ross RK, et al. Intake of vegetables, fruits, beta-carotene, vitamin $\mathrm{C}$ and vitamin supplements and cancer incidence among the elderly: a prospective study. Br J Cancer 1992;66:673-9.

19. Malila N, Virtamo J, Virtanen M, et al. Dietary and serum alpha-tocopherol, beta-carotene and retinol, and risk for colorectal cancer in male smokers. Eur J Clin Nutr 2002;56: 615-21.

20. Terry P, Jain M, Miller AB, et al. Dietary carotenoid intake and colorectal cancer risk. Nutr Cancer 2002;42:167-72.

21. Enger SM, Longnecker MP, Chen M-J, et al. Dietary intake of specific carotenoids and vitamins $\mathrm{A}, \mathrm{C}$, and $\mathrm{E}$, and prevalence of colorectal adenomas. Cancer Epidemiol Biomarkers Prev 1996;5:147-53.

22. Malila N, Virtamo J, Virtanen M, et al. The effect of alphatocopherol and beta-carotene supplementation on colorectal adenomas in middle-aged male smokers. Cancer Epidemiol Biomarkers Prev 1999;8:489-93.

23. Levin B. Potential pitfalls in the use of surrogate endpoints in colorectal adenoma chemoprevention. J Natl Cancer Inst 2003;95:697-9.

24. Baron JA, Cole BF, Mott L, et al. Neoplastic and antineoplastic effects of beta-carotene on colorectal adenoma recurrence: results of a randomized trial. J Natl Cancer Inst 2003;95: 717-22.

25. Hennekens CH, Buring JE, Manson JE, et al. Lack of effect of long-term supplementation with beta carotene on the incidence of malignant neoplasms and cardiovascular disease. N Engl J Med 1996;334:1145-9.

26. Albanes D, Malila N, Taylor PR, et al. Effects of supplemental alpha-tocopherol and beta-carotene on colorectal cancer: results from a controlled trial (Finland). Cancer Causes Control 2000;11:197-205.

27. Slattery ML, Benson J, Curtin K, et al. Carotenoids and colon cancer. Am J Clin Nutr 2000;71:575-82.

28. La Vecchia C. Tomatoes, lycopene intake, and digestive tract and female hormone-related neoplasms. Exp Biol Med (Maywood) 2002;227:860-3.

29. Satia-Abouta J, Galanko JA, Martin CF, et al. Associations of micronutrients with colon cancer risk in African Americans and whites: results from the North Carolina Colon Cancer Study. Cancer Epidemiol Biomarkers Prev 2003;12:747-54.

30. Smith-Warner SA, Spiegelman D, Ritz J, et al. Methods for pooling results of epidemiologic studies: The Pooling Project of Prospective Studies of Diet and Cancer. Am J Epidemiol 2006;163:1053-64.

31. Steinmetz KA, Kushi LH, Bostick RM, et al. Vegetables, fruit, and colon cancer in the Iowa Women's Health Study. Am J Epidemiol 1994;139:1-15.

32. Bandera EV, Freudenheim JL, Marshall JR, et al. Diet and alcohol consumption and lung cancer risk in the New York State Cohort (United States). Cancer Causes Control 1997;8: 828-40.

33. Michels KB, Giovannucci E, Joshipura KJ, et al. Prospective study of fruit and vegetable consumption and incidence of colon and rectal cancers. J Natl Cancer Inst 2000;92:1740-52.

34. Voorrips LE, Goldbohm RA, van Poppel G, et al. Vegetable and fruit consumption and risks of colon and rectal cancer in a prospective cohort study: The Netherlands Cohort Study on Diet and Cancer. Am J Epidemiol 2000;152:1081-92.

35. Flood A, Velie EM, Chaterjee N, et al. Fruit and vegetable intakes and the risk of colorectal cancer in the Breast Cancer Detection Demonstration Project follow-up cohort. Am J Clin Nutr 2002;75:936-43.

36. McCullough ML, Robertson AS, Chao A, et al. A prospective study of whole grains, fruits, vegetables, and colon cancer risk. Cancer Causes Control 2003;14:959-70. 
37. Higginbotham S, Zhang Z-F, Lee I-M, et al. Dietary glycemic load and risk of colorectal cancer in the Women's Health Study. J Natl Cancer Inst 2004;96:229-33.

38. Terry P, Giovannucci E, Michels KB, et al. Fruit, vegetables, dietary fiber, and risk of colorectal cancer. J Natl Cancer Inst 2001;93:525-33.

39. Singh PN, Fraser GE. Dietary risk factors for colon cancer in a low-risk population. Am J Epidemiol 1998;148: 761-74.

40. Kato I, Akhmedkhanov A, Koenig K, et al. Prospective study of diet and female colorectal cancer: The New York University Women's Health Study. Nutr Cancer 1997;28: 276-81.

41. Sieri S, Krogh V, Muti P, et al. Fat and protein intake and subsequent breast cancer risk in postmenopausal women. Nutr Cancer 2002;42:10-17.

42. Prentice RL. A case-cohort design for epidemiologic cohort studies and disease prevention trials. Biometrika 1986;73: $1-11$.

43. Larsson SC, Rafter J, Holmberg L, et al. Red meat consumption and risk of cancers of the proximal colon, distal colon and rectum: The Swedish Mammography Cohort. Int J Cancer 2005;113:829-34.

44. Willett WC, Sampson L, Stampfer MJ, et al. Reproducibility and validity of a semiquantitative food frequency questionnaire. Am J Epidemiol 1985;122:51-65.

45. Pietinen P, Hartman AM, Haapa E, et al. Reproducibility and validity of dietary assessment instruments. I. A selfadministered food use questionnaire with a portion size picture booklet. Am J Epidemiol 1988;128:655-66.

46. Munger RG, Folsom AR, Kushi LH, et al. Dietary assessment of older Iowa women with a food frequency questionnaire: nutrient intake, reproducibility, and comparison with 24hour dietary recall interviews. Am J Epidemiol 1992;136: 192-200.

47. Rimm EB, Giovannucci EL, Stampfer MJ, et al. Reproducibility and validity of an expanded self-administered semiquantitative food frequency questionnaire among male health professionals. Am J Epidemiol 1992;135:1114-26.

48. Feskanich D, Marshall J, Rimm EB, et al. Simulated validation of a brief food frequency questionnaire. Ann Epidemiol 1994;4:181-7.

49. Goldbohm RA, van den Brandt PA, Brants HA, et al. Validation of a dietary questionnaire used in a large-scale prospective cohort study on diet and cancer. Eur J Clin Nutr 1994;48:253-65.

50. Jain M, Howe GR, Rohan T. Dietary assessment in epidemiology: comparison of a food frequency and a diet history questionnaire with a 7-day food record. Am J Epidemiol 1996; 143:953-60.

51. Flagg EW, Coates RJ, Calle EE, et al. Validation of the American Cancer Society Cancer Prevention Study II Nutrition Survey Cohort food frequency questionnaire. Epidemiology 2000;11:462-8.

52. Willett W, Stampfer MJ. Total energy intake: implications for epidemiologic analyses. Am J Epidemiol 1986;124:17-27.

53. Messerer M, Johansson SE, Wolk A. The validity of questionnaire-based micronutrient intake estimates is in- creased by including dietary supplement use in Swedish men. J Nutr 2004;134:1800-5.

54. Cox DR. Regression models and life tables (with discussion). J R Stat Soc B 1972;34:187-220.

55. SAS Institute, Inc. SAS/STAT software: the PHREG procedure: preliminary documentation. Cary, NC: SAS Institute, Inc, 1991.

56. DerSimonian R, Laird N. Meta-analysis in clinical trials. Control Clin Trials 1986;7:177-88.

57. Cochran WG. The combination of estimates from different experiments. Biometrics 1954;10:101-29.

58. Stram DO. Meta-analysis of published data using a linear mixed-effects model. Biometrics 1996;52:536-44.

59. Anderson TW. Introduction to multivariate statistics. 2nd ed. New York, NY: John Wiley \& Sons, Inc, 1984.

60. Prentice RL, Breslow NE. Retrospective studies and failure time models. Biometrika 1978;65:153-8.

61. Rock CL, Flatt SW, Wright FA, et al. Responsiveness of carotenoids to a high vegetable diet intervention designed to prevent breast cancer recurrence. Cancer Epidemiol Biomarkers Prev 1997;6:617-23.

62. Nair S, Norkus EP, Hertan H, et al. Serum and colon mucosa micronutrient antioxidants: differences between adenomatous polyp patients and controls. Am J Gastroenterol 2001;96: 3400-5.

63. Mühlhöfer A, Buhler-Ritter B, Frank J, et al. Carotenoids are decreased in biopsies from colorectal adenomas. Clin Nutr 2003;22:65-70.

64. Britton G. Structure and properties of carotenoids in relation to function. FASEB J 1995;9:1551-8.

65. Rock CL. Carotenoids: biology and treatment. Pharmacol Ther 1997;75:185-97.

66. Briviba K, Schnabele K, Schwertle E, et al. Beta-carotene inhibits growth of human colon carcinoma cells in vitro by induction of apoptosis. Biol Chem 2001;382:1663-8.

67. Paalanen L, Männistö S, Virtanen MJ, et al. Validity of a food frequency questionnaire varied by age and body mass index. J Clin Epidemiol 2006;59:994-1001.

68. Henderson IC, Patek AJ. Are breast cancers in young women qualitatively distinct? Lancet 1997;349:1488-9.

69. Schober SE, Comstock GW, Helsing KJ, et al. Serologic precursors of cancer. I. Prediagnostic serum nutrients and colon cancer risk. Am J Epidemiol 1987;126:1033-41.

70. Omenn GS, Goodman GE, Thornquist MD, et al. Risk factors for lung cancer and for intervention effects in CARET, the Beta-Carotene and Retinol Efficacy Trial. J Natl Cancer Inst 1996;88:1550-9.

71. Steinmetz KA, Potter JD. Vegetables, fruit, and cancer prevention: a review. J Am Diet Assoc 1996;96:1027-39.

72. de Vogel J, Jonker-Termont DS, van Lieshout EM, et al. Green vegetables, red meat and colon cancer: chlorophyll prevents the cytotoxic and hyperproliferative effects of haem in rat colon. Carcinogenesis 2005;26:387-93.

73. Strohle A, Wolters M, Hahn A. Folic acid and colorectal cancer prevention: molecular mechanisms and epidemiological evidence. Int J Oncol 2005;26:1449-64.

74. Bianchini F, Vainio H. Isothiocyanates in cancer prevention. Drug Metab Rev 2004;36:655-67. 